\title{
$\begin{array}{r}\text { WAGENINGEN } \\ \text { UNIVERSITY \& RESEARCH } \\ \hline\end{array}$
}

\section{Hazard assessment of Maerua subcordata (Gilg) DeWolf. for selected endpoints using a battery of in vitro tests}

Gebrelibanos Hiben, M., Kamelia, L., de Haan, L., Spenkelink, B., Wesseling, S., Vervoort, J., \& Rietjens, I. M. C. M.

This is a "Post-Print" accepted manuscript, which has been published in "Journal of Ethnopharmacology"

This version is distributed under a non-commercial no derivatives Creative Commons (c) (1) $\$(9)$ reproduction in any medium, provided the original work is properly cited and not used for commercial purposes. Further, the restriction applies that if you remix, transform, or build upon the material, you may not distribute the modified material.

Please cite this publication as follows:

Gebrelibanos Hiben, M., Kamelia, L., de Haan, L., Spenkelink, B., Wesseling, S., Vervoort, J., \& Rietjens, I. M. C. M. (2019). Hazard assessment of Maerua subcordata (Gilg) DeWolf. for selected endpoints using a battery of in vitro tests. Journal of Ethnopharmacology, 241, [111978]. https://doi.org/10.1016/j.jep.2019.111978 


\section{Hazard Assessment of Maerua subcordata (Gilg) DeWolf. for Selected Endpoints using a Battery of In Vitro Tests}

Mebrahtom Gebrelibanos Hiben ${ }^{1,2^{*}}$, Lenny Kamelia ${ }^{1}$, Laura de Haan ${ }^{1}$, Bert Spenkelink ${ }^{1}$, Sebastiaan Wesseling ${ }^{1}$, Jacques Vervoort ${ }^{3}$, Ivonne M.C.M. Rietjens ${ }^{1}$

${ }^{1}$ Division of Toxicology, Wageningen University \& Research, Stippeneng 4, 6708WE

Wageningen, The Netherlands; ${ }^{2}$ Department of Pharmacognosy, School of Pharmacy, College of Health Sciences, Mekelle University, Mekelle, Ethiopia. ${ }^{3}$ Laboratory of Biochemistry, Wageningen University, Stippeneng 4, 6708WE Wageningen, The Netherlands.

Mebrahtom Gebrelibanos Hiben: mebrahtomgs@yahoo.com or mebrahtom.hiben@wur.nl Lenny Kamelia: lenny.kamelia@wur.nl

Laura de Haan: laura.dehaan@wur.nl

Bert Spenkelink: bert.spenkelink@wur.nl

Sebastiaan Wesseling: sebas.wesseling@,wur.nl

Jacques Vervoort: jacques.vervoort@,wur.nl

Ivonne M.C.M. Rietjens: ivonne.rietjens@wur.nl

\section{*Address for correspondence:}

${ }^{1}$ Division of Toxicology, Wageningen University \& Research, Stippeneng 4, 6708WE Wageningen, The Netherlands; Building/room 124/4037. ${ }^{2}$ Department of Pharmacognosy, School of Pharmacy, College of Health Sciences, Mekelle University, Mekelle, Ethiopia, Tel. (+251) 911183120 Fax. (+251) 344416681, e-mail: mebrahtomgs@yahoo.com or mebrahtom.hiben@wur.nl 


\section{Abstract}

Ethnopharmacological Relevance: Maerua subcordata (Gilg) DeWolf is a medicinal and wild food plant growing mainly in east Africa. Especially its root tuber is widely used in traditional medicine to treat several infectious and chronic diseases but also in some toxicity implications like use as abortifacient.

Aim of the study: the present study applied in silico and in vitro tests to identify possible hazards of M. subcordata (fruit, leaf, root, seed) methanol extracts focusing on developmental toxicity.

Materials and methods: Ames test, estrogen receptor alpha (ER $\alpha)$ assay, aryl hydrocarbon receptor (AhR) assay, embryonic stem cell test (EST), and zebrafish embryotoxicity test (ZET) were employed. Besides, a Derek Nexus toxicity prediction was performed on candidate structures obtained from metabolomics profiling of the extracts using liquid chromatography coupled to multistage mass spectroscopy $\left(\mathrm{LC} / \mathrm{MS}^{\mathrm{n}}\right)$ and a MAGMa software based structural annotation.

Results: Glucosinolates, which degrade to isothiocyanates, and biogenic amines were among the candidate molecules identified in the extracts by LC/MS ${ }^{\mathrm{n}}$ - MAGMa software structural annotation. Isothiocyanates and some other candidate molecules suggested a positive mutagenicity alert in Derek toxicity predictions. All the extracts showed negative mutagenicity in the Ames test. However, the Derek predictions also identified endocrine and developmental toxicity as possible endpoints of concern. This was further assessed using in vitro tests. Results obtained reveal that leaf extract shows AhR and ER $\alpha$ agonist activities, inhibited differentiation of ES-D3 stem cells into contracting cardiomyocytes in the EST $(\mathrm{p}<0.001)$ as well as inhibited hatching $(\mathrm{p}<0.01)$ and showed acute toxicity $(\mathrm{p}<0.01)$ in the ZET. Also, the fruit extract showed toxicity $(\mathrm{p}<0.05)$ towards zebrafish embryos and both 
fruit and seed extracts showed AhR agonist activities while root extract was devoid of activity in all in vitro assays.

Conclusion: The leaf extract tests positive in in vitro tests that this may point towards a developmental toxicity hazard. The current evaluations did not raise concerns of genotoxicity or developmental toxicity for the fruit, seed and root extracts. This is important given the use of especially these parts of M. subcordata, in traditional medicine and/or as (famine) food.

Key words: CALUX assays, in vitro, Maerua subcordata, hazard, embryonic stem cell test, zebrafish embryotoxicity test

\section{Introduction}

Human exposure to natural ingredients of botanical origin, particularly via the use of dietary supplements and herbal medicines, continues to rise globally (Paine and Roe,2018; Roe et al., 2018). The general misconception that "natural" always means "safe" together with the improved scientific data and understanding of the beneficial health effects of bioactive substances in plant foods and medicinal products have boosted worldwide use of botanicals (Mahady et al., 2001; Kroes and Walker, 2004; Rietjens et al., 2008; Fürst and Zündorf,, 2015; Onyeji et al., 2017; Salehi et al., 2018; Sharifi-Rad et al., 2018). Thus, both consumers and industry have a rising interest towards the development of food products, having 'functional' properties or health benefits, derived from botanicals ranging from staple food sources like cereals, fruits and vegetables, to herbals used in traditional medicine (Schilter et al., 2003; Rietjens et al., 2008). However, users may also get exposed to possible health hazards arising from inherent constituents or contaminants of botanical products that may 
lead to adverse health effects (Schilter et al., 2003; Fürst and Zündorf, 2015) and hence, there is a need to evaluate their hazards and safety.

Toxicity studies of botanicals are challenging and complicated due to, among others, costs, time, and animal usage as well as the complex mixtures of constituents that show variability in composition, (Kroes and Walker, 2004; Little et al., 2017). Still, an integrative testing strategy has been suggested tailored to hazard assessment using a panel of available alternative tests for critical end points that provides optimal in silico and in vitro filters (Piersma, 2013) aimed to assess hazards of botanical products especially when safety data are insufficient and as an early screen for toxicity alerts, particularly for less commonly known botanicals (Roe et al., 2018). Some suggested alternative methods include an in silico decision tree approach (Kroes and Walker, 2004; Little et al.,2017), a battery of in vitro tests such as assays for genotoxicity, CALUX reporter gene assays, the embryonic stem cell test (EST), and the zebrafish embryotoxicity test (ZET) (Hoogenboom et al., 2006; Besselink et al., 2015; Kroese et al., 2015; Piersma et al., 2013; Haedrich et al., 2018; Prinsloo et al., 2017).

A long history of use in traditional medicine of a botanical material is generally assumed as an indicator of lack of obvious toxicity (Trease and Evans, 2002). Yet, safety issues need scientific justification if use of a botanical material is to be considered. Maerua subcordata (Gilg) DeWolf (Capparidaceae), a medicinal and famine food plant, has numerous traditional uses but it lacks scientific data on its potential health hazards and health benefits. Its tuber is claimed as safe antimalarial remedy for children and pregnant women in northern Ethiopia, where collection of plant material in the present study was made, while reports from Somalia show that the same plant part is used as abortifacient (Samuelsson et al. 1985, 1991), which, if the later claim is true, may point at a possible adverse effect. Moreover, few reports reflect 
that M. subcordata could be potentially toxic to humans and animals. It has been marked as a noxious shrub, which is potentially toxic to wildlife and cattle (Strauch and Eby, 2012). Human safety concern could be that uncooked fruits are perceived as toxic unless well boiled to render them to be non-toxic and edible (Morgan, 1981; Wigrup, 2005). Also, possible intoxication by quaternary ammonium compounds in the root was suspected, although such a problem was not detected along the area of the Omo river where the root is commonly used as a water clarifying agent; maybe because the quantities ending up in the water were too small to cause negative health effects (Göttsch, 1992). Scientific data on M. subcordata are lacking. A study with brine shrimp (Artemia salina Leach) showed that a methanolic root extract was inactive $\left(\mathrm{LC}_{50}>1000 \mu \mathrm{g} / \mathrm{ml}\right)$ against the tested organism (Gakuya et al., 2004) which could be an indication of absence of obvious toxicity, at least to this species. Therefore, considering these ethno-toxicological claims, the aim of the present study was to investigate the possible hazards related to use of parts or extracts of M. subcordata given that various ethno-medicinal claims on $M$. subcordata may point towards its potential uses as source of herbal medicine or as functional or famine food. A Derek Nexus toxicity prediction, performed on candidate structures obtained from metabolomics profiling of the extracts, was used to direct selection of the in vitro tests to be employed. Different in vitro tests were applied to assess especially the genotoxicity, and endocrine and developmental toxicity hazards of M. subcordata (fruit, leaf, root, and seed) methanol extracts.

\section{Materials and Methods}

\subsection{Plant material: collection, authentication, and processing}

The fruit, leaf, root tuber, and seed parts of M. subcordata (Voucher number MG001/2007) were obtained from plants collected at 'lemlem' sub-district near shiraro $\left(14.3970^{\circ} \mathrm{N}\right.$, $37.7743^{\circ}$ E) in Northwest Tigray, Northern Ethiopia. The fruit, leaf, and seed parts were dried at room temperature while the tuber was first chopped into small pieces and dried in an 
oven at $40{ }^{\circ} \mathrm{C}$. The dried plant materials were packed in plastic bags, transported to the

Division of Toxicology, Wageningen University \& Research, the Netherlands; where they were further processed and tested. To remove moisture and facilitate powdering, each dried plant part was splashed with liquid nitrogen and then ground using an analytical electric mill, mixed well, packed in capped plastic tubes, and stored at $-80{ }^{\circ} \mathrm{C}$ until further use.

\subsection{Cell lines}

$\mathrm{ER} \alpha \mathrm{CALUX}^{\circledR}, \mathrm{Cytotox}^{\mathrm{CALUX}}{ }^{\circledR}$, and DR $\mathrm{CALUX}^{\circledR}$ cell lines were obtained from Bio

Detection Systems BV (Amsterdam, The Netherlands). The pluripotent mouse ES-D3 cell line used for the EST was obtained from ATCC (ATCC ${ }^{\circledR}$ CRL 1934TM, Wesel, Germany). The ER $\alpha$ CALUX cells are human bone osteosarcoma U2OS cells stably transfected with a firefly luciferase gene coupled to estrogen responsive elements (EREs) as a reporter gene to detect estrogen receptor agonists and antagonists (Besselink et al., 2015). The Cytotox CALUX cells are human osteosarcoma U2OS cells stably transfected with a reporter construct carrying a luciferase reporter gene under transcriptional control of a constitutive promoter. These cells have an invariant luciferase expression and were originally designed to study cytotoxicity (van der Linden et al., 2014). The ER $\alpha$ CALUX and Cytotox CALUX cells were cultured in Minimum Essential Medium alpha 1:1 mixture of Dulbecco's modified Eagle's medium and Ham's F12 medium (DMEM/F12) (Gibco life technology ${ }^{\mathrm{TM}}$, Paisley, UK), supplemented with 7.5\% foetal calf serum (FCS) (Gibco life technology ${ }^{\mathrm{TM}}$, Paisley, UK), and $1 \%$ nonessential amino acids (NEAA) (Invitrogen Corporation Breda, The Netherlands). The DR-CALUX cells are cells from a rat hepatoma (H4IIE) cell line, stably transfected with a construct containing the dioxin-responsive element sequence coupled to an AhR regulated luciferase reporter gene (H4I1E-luc) (Aarts et al.,1995; Bekki et al., 2009). The DR-CALUX cells were cultured in Minimum Essential Medium alpha ( $\alpha$-MEM) ) 
148 (Gibco life technology ${ }^{\mathrm{TM}}$, Paisley, UK) supplemented with 10\% FCS (Murk et al., 1996; 149 Bekki et al., 2009). The U2OS ER $\alpha$, U2OS Cytotox, and H4IIE.luc (DR CALUX) cells were incubated at $37^{\circ} \mathrm{C}$ with $5 \% \mathrm{CO}_{2}$ in a humidified atmosphere and subcultured every $2-3$ days, using $0.05 \%$ trypsin-EDTA to detach the cells. The ES-D3 cell line used for the EST was maintained in $25 \mathrm{~cm}^{2}$ polystyrene cell culture flasks (Corning, the Netherlands), pre-coated with $0.1 \%$ gelatine, in HyClone AdvanceSTEM ${ }^{\mathrm{TM}}$ Low Osmo Dulbecco's Modified Eagle Medium (DMEM) (Fischer Scientific, Landsmeer, the Netherlands) supplemented with 15\% Fetal Bovine Serum (FBS) (ATCC, USA), 2 mM L-glutamine (Invitrogen, The Netherlands), $50 \mathrm{U} / \mathrm{ml}$ penicillin (Invitrogen) and $50 \mu \mathrm{g} / \mathrm{ml}$ streptomycin (Invitrogen). Cells were routinely subcultured every 2-3 days using non-enzymatic cell dissociation solution (Sigma-Aldrich, Schnelldorf, Germany) to detach the cells and were kept undifferentiated by the addition of $1000 \mathrm{U} / \mathrm{ml}$ murine Leukemia Inhibiting Factor (mLIF) (Sigma-Aldrich) (Kamelia et al., 2017). The ES-D3 cells were incubated at $37^{\circ} \mathrm{C}$ and $5 \% \mathrm{CO}_{2}$ in a humidified atmosphere.

\subsection{Zebrafish eggs}

Eggs of zebrafish (Danio rerio) wild-type AB line, produced by group spawning were obtained from the Animal Sciences Group of Wageningen University \& Research; CarusARF Bornse Weilanden 5, 6708 WG Wageningen, the Netherlands.

\subsection{Preparation of extracts from Maerua subcordata}

Methanol extracts from dried powders of different parts - fruit, leaf, root tuber, and seed- of M. subcordata were prepared by adding $3.4 \mathrm{ml}$ methanol to $0.6 \mathrm{~g}$ of powdered plant material followed by sonication for $10 \mathrm{~min}$ and centrifugation at $1000 \mathrm{~g}$ for $15 \mathrm{~min}$. The supernatant was filtered using $0.2 \mu \mathrm{m}$ polytetrafluoroethylene (PTFE)-filters (Whatman ${ }^{\mathrm{TM}}$, Germany) and freeze-dried after the methanol was evaporated under a stream of nitrogen. Dried extracts were stored at $-80{ }^{\circ} \mathrm{C}$ until used. For screening in the ER $\alpha$ CALUX and Cytotox CALUX 
assays, the extracts were re-dissolved in DMSO:DMEM $(1: 2 \mathrm{v} / \mathrm{v})$ while for screening in the DR-CALUX, EST, Ames test, and ZET, the extracts were re-dissolved in DMSO (SigmaAldrich).

\subsection{Ames Test}

The plate incorporation method of the Ames test was used to screen the mutagenicity of $M$. subcordata fruit, leaf, root, and seed extracts at concentrations of 15, 30, and 60 milligram dry weight $(\mathrm{mgDW})$ per plate. The extracts were tested with and without metabolic activation as described by Ames et al., (1975) and with adaptions of the principles of the OECD 471 guideline (OECD, 1997). Briefly, $0.1 \mathrm{ml}$ test extracts or $0.25 \%(\mathrm{v} / \mathrm{v})$ DMSO (solvent control), $0.1 \mathrm{ml}$ overnight bacterial (Salmonella typhimurium, TA98 or TA100) culture $(1 \mathrm{x}$ $10^{8}$ cells $/ \mathrm{ml}$ ), and $0.3 \mathrm{ml} \mathrm{S9}$ mixture (11-403L MUTAZYME 5\% S9 from Aroclor 1254induced male SD rat liver, reconstituted with $20 \mathrm{ml}$ cold sterile water) or PBS (for tests without metabolic activation) were added into $2 \mathrm{ml}$ top agar in test tubes. The contents were mixed and poured onto the surface of a glucose minimal plate. After solidification, plates were incubated upside down at $37{ }^{\circ} \mathrm{C}$ for $72 \mathrm{hr}$. At the end of the incubation, revertant colonies were counted. For each test, an average revertant colony count of three independent experiment was presented. A test plate was considered positive for mutagenicity if it produced a number of revertant colonies significantly higher ( $>$ twofold) than spontaneous revertant colonies on the solvent control plate, or otherwise considered a negative result.

\subsection{Metabolomics profiling and toxicity prediction}

M. subcordata methanol extracts $(5 \mu 1)$ were injected onto a C18 column (Phenomenex Luna $150 \times 2 \mathrm{~mm}$ i.d., $3 \mu \mathrm{m}$ Torrance, USA) of an Ultimate 3000 UPLC with a 60 minutes gradient and measured on a Q Exactive Orbitrap FTMS System (Thermo Scientific, Bremen) in both positive and negative mode. The raw data were converted into mzXML by the ProteoWizard 
MSconvert software. Structural characterization was supported by 'MS Annotation based on in silico Generated Metabolites' (MAGMa) (http://www.emetabolomics.org/magma) software (Ridder et al., 2012). Uploaded spectral data were automatically annotated with tiered trees of in silico generated substructures of candidates, retrieved from a subset of compounds present in Kegg. Candidate structures thought to be most likely present in the extracts were manually selected from the MAGMa user interface. The identity of selected candidates was further confirmed by LC-MS/MS (Shimadzu LC-MS 8040) based on multiple reaction monitoring (MRM) using market available standard compounds such as stachydrine hydrochloride, trigonelline hydrochloride (PhytoLab,Vestenbergsgreuth,Germany), glucolepidiin potassium, glucobrassicin potassium (Extrasynthese,Genay Cedex,France). Likewise, although structures of pyrrolizidine alkaloids (PAs) such as senecionine or senecivernine were in the tentative identification, their presence in the extracts was ruled out by further LC-MS/MS analysis using different standard mixture of PAs and with $\leq 1 \mu \mathrm{g} / \mathrm{g}$ limit of detection. Toxicity prediction for query structures was performed using Derek Nexus, a software program developed by Lhasa Ltd. (https://www.lhasalimited.org/) (Worth et al., 2010). In Derek, toxicity predictions are the result of two processes: (i) the program checks whether any alerts in its knowledge base match toxicophores (substructures known or thought to be responsible for a particular effect or toxicity) in the query structure and (ii) the reasoning engine assesses the likelihood of a structure being toxic described by nine confidence levels that were converted into three categories: active (certain, probable, plausible), equivocal, and not active (doubted, improbable, impossible, open, and contradicted) (Worth et al., 2010).

\subsubsection{DR CALUX assay (AhR assay)}

The AhR agonistic activities of $M$. subcordata methanol extracts were measured by the DR 
inner wells of a white 96-well view plate at a density of $3 \times 10^{4}$ cells per well in $100 \mu \mathrm{L}$ culture medium while $200 \mu \mathrm{l}$ PBS was added to the outer 36 wells. After $24 \mathrm{hr}$ incubation, the cells were inspected under a microscope and then exposed to $30 \mathrm{pM} 2,3,7,8-$ tetrachlorodibenzo- $p$-dioxin (TCDD) (Sigma-Aldrich), as positive control, $0.5 \%(\mathrm{v} / \mathrm{v}) \mathrm{DMSO}$ as solvent control, and varying concentrations $(0.024-12 \mathrm{gDW} / \mathrm{L})$ of extracts in $100 \mu 1$ exposure medium in the same plate. The final DMSO concentration in the incubations was $0.5 \%(\mathrm{v} / \mathrm{v})$. After $6 \mathrm{hr}$ or $24 \mathrm{hr}$ exposure, medium was removed, cells were washed with $1 / 2$ PBS (PBS half diluted with nano pure water), and exposed to $30 \mu 1$ low salt lysing buffer (1.212 g Tris, $0.084 \mathrm{~g}$ dithiothreitol, $0.73 \mathrm{~g}$ 1,2-cyclohexylenedinitrilotetraacetic acid in a litre of nano pure water, $\mathrm{pH}$ 7.8) was added to each well to lyse the cells. Then, plates were covered with aluminium foil, placed on ice for 15 minutes and frozen overnight at $-80{ }^{\circ} \mathrm{C}$. For the luminescence measurement, plates were thawed at room temperature and luciferase activity per well in the lysate was measured in relative light units (RLU) using a luminometer (GloMax ${ }^{\circledR}$-Multi Detection System-Promega) after the addition to each well of $100 \mu$ flash mix $\left(20 \mathrm{mM}\right.$ Tricine, $1.07 \mathrm{mM}\left(\mathrm{MgCO}_{3}\right)_{4} \mathrm{Mg}(\mathrm{OH})_{2}, 2.67 \mathrm{mM} \mathrm{MgSO}_{4} .7 \mathrm{H}_{2} \mathrm{O}, 0.1 \mathrm{mM}$ EDTA, $2.0 \mathrm{mM}$ dithiothreitol, $470 \mu \mathrm{M}$ luciferine, $5.0 \mathrm{mM}$ ATP; in a litre of nano pure water, $\mathrm{pH}$ 7.8). At least three independent experiments were conducted and results were expressed as fold induction of luciferase activity compared to the solvent control.

\subsubsection{ER $\alpha$ CALUX and Cytotox CALUX assays}

240 The cytotox CALUX assay was done in the same way and parallel to every ER $\alpha$ CALUX assay because Cytotox CALUX cells serve as indicators of cytotoxicity or non-specific increases in luciferase activity. In brief, cells were seeded in the 60 inner wells of a white 96well view plate at a density of $1 \times 10^{4}$ cells per well in $100 \mu$ assay medium: DMEM/F12 supplemented with $7.5 \%$ FCS, and 1\% NEAA. The outer wells were filled with $200 \mu 1$ PBS and the plates were incubated for $24 \mathrm{hr}$. The next day, the assay medium was carefully 
removed from the wells with cells, and replaced by $100 \mu \mathrm{l}$ of fresh assay medium. The plates

247 were incubated for another $24 \mathrm{hr}$. Then $100 \mu \mathrm{l}$ exposure medium containing the test samples was added to each well resulting in $200 \mu \mathrm{l}$ per well assay medium. After $24 \mathrm{hr}$ exposure, medium was removed, cells were washed with $1 / 2$ PBS, lysed with low salt buffer, frozen overnight and luciferase activity was measured in the same way as described above for the AhR CALUX assay.

\subsubsection{ES-D3 cell viability and differentiation assays}

\section{ES-D3 cell viability assay}

254

The cytotoxicity of the test extracts to ES-D3 cells was assessed by the WST-1 assay which measures the extent of conversion of tetrazolium salts into a formazan dye by mitochondrial enzymes in metabolically active cells. The ES-D3 cell viability assay was done as previously described by Kamelia et al., 2017. Briefly, ES-D3 cells were seeded in 96-well plates (Greiner Bio-One, Alphen a/d Rijn, the Netherlands) at a density of $2 \times 10^{5}$ cells/ml (one day exposure) or $10^{4}$ cells/ml (five days exposure) in $100 \mu$ medium (without mLIF) and incubated for one day to facilitate cell adherence. Then, cells were exposed to $100 \mu \mathrm{l}$ of medium with or without test extracts (3 replicates/concentration) and incubated for one day or five days at $37{ }^{\circ} \mathrm{C}$ and $5 \% \mathrm{CO}_{2}$. All extracts were tested at a range of concentrations up to $1500 \mathrm{mgDW} / \mathrm{L}$. The final concentration of DMSO was kept at $0.25 \%(\mathrm{v} / \mathrm{v})$. After the incubation period, $20 \mu \mathrm{l}$ of WST-1 reagent (Roche Diagnostics, Mannheim, Germany) was added to each well and cells were incubated for $3 \mathrm{~h}$ at $37{ }^{\circ} \mathrm{C}$ and $5 \% \mathrm{CO}_{2}$. Subsequently, the absorbance of the formed formazan was measured at $440 \mathrm{~nm}$ using a SpectraMax M2 (Molecular Devices, Sunnyvale, USA). Cell viability was expressed as percentage of cell viability compared to the solvent control which was set at $100 \%$. Wells containing culture medium without cells plus WST-1 reagent were used as a blank (background control) and 
used to define $0 \%$ viability. At least three independent experiments were done for each test extract, and results were expressed as \% viability compared to the solvent control.

\section{ES-D3 cell differentiation assay}

The inhibitory potential of test extracts on differentiation of ES-D3 cells into contracting cardiomyocytes was assessed using the ES-D3 cell differentiation assay of the embryonic stem cell test (EST) as described by Kamelia et al. (2017). The first step of the differentiation assay is the formation of embryoid bodies (EBs) via hanging drop culture in medium without mLIF. On day 0 , droplets of $20 \mu \mathrm{l}$ of a cell suspension $\left(3.75 \times 10^{4}\right.$ cells $\left./ \mathrm{ml}\right)$, with or without test sample, were placed between the well borders on the inner side of the lid of a 96-well plate. The wells of the 96-well plate were filled with $250 \mu$ of PBSto create an optimal humidity and to prevent evaporation of the hanging drops. Sterile caps of Eppendorf tubes were placed in the corner of the plates in order to prevent direct contact of the drops with the plate and the plate was subsequently sealed with Micropore tape (3M, Neuss, Germany) to prevent evaporation of the hanging drops. The hanging drop cultures were incubated for three days at $37{ }^{\circ} \mathrm{C}$ and $5 \% \mathrm{CO}_{2}$. On day 3, the resulting EBs were transferred to $60 \times 15 \mathrm{~mm}$ bacteriological petri dishes (Greiner Bio-One) containing $5 \mathrm{ml}$ medium, with or without test samples. The petri dishes were incubated for another 2 days at $37{ }^{\circ} \mathrm{C}$ and $5 \% \mathrm{CO}_{2}$ in the presence or absence of the test extracts. On day 5, the EBs were transferred to a 24-well plate (Corning) (1 EB/well), containing $1 \mathrm{ml}$ medium with or without test extract. The EBs in 24well plates were then incubated for 5 days at $37{ }^{\circ} \mathrm{C}$ and $5 \% \mathrm{CO}_{2}$. On day 10 , the number of wells containing contracting cardiomyocytes was determined by visual inspection using a light microscope. The concentration of solvent in the medium was kept at $0.25 \%(\mathrm{v} / \mathrm{v}) \mathrm{DMSO}$. A solvent control and positive control of 5-fluorouracil (Sigma-Aldrich), final concentration $0.065 \mu \mathrm{g} / \mathrm{ml}(0.5 \mu \mathrm{M})$ were included in each experiment. This assay was considered valid if the solvent control had at least 21 out of 24 wells that contained contracting cardiomyocytes. 
Inhibition of differentiation by the test extracts was presented as the fraction of total EBs

plated in the 24-well plate that contained beating cardiomyocytes and at least three independent experiments were done for each test extract.

\subsection{Zebrafish embryotoxicity (ZET) Test}

The ZET assay was performed considering the principles of the OECD 236 guideline (OECD 236, 2013) and the method described by Beekhuijzen et al., (2015). Zebrafish (Danio rerio) wild-type $\mathrm{AB}$ line eggs produced via group spawning were sorted at about 1-3 hours post fertilization (hpf) in petri dishes using a disposable plastic pipette under the microscope. Since not all the eggs were fertilized, only the fertilized eggs with normal development stages were selected and placed in the incubator until exposure at $4 \mathrm{hpf}$. The test was done in 24well plates. Each plate was used for exposure of embryos to one concentration of test extract. In every 24 -well plate, 20 wells were filled with $2 \mathrm{ml}$ of exposure medium (one concentration of test sample) while 4 wells were filled with $2 \mathrm{ml}$ egg water for use as internal control. One embryo of the selected fertilized eggs was transferred to every well using a disposable plastic pipette. Methanol extracts of $M$. subcordata fruit, leaf, root, and seed parts were re-dissolved in DMSO and tested at final concentrations of $150,375,750,1125$, and 1500 milligrams dry weight per litre $(\mathrm{mgDW} / \mathrm{L})$ added from $600 \mathrm{gDW} / \mathrm{L}$ stock solution in DMSO, the final DMSO concentration was $0.25 \%(\mathrm{v} / \mathrm{v})$. Plates were then sealed with self-adhesive film cover to prevent further evaporation of test compound throughout the exposure period (up to 96 hpf). Plates were incubated at $26^{\circ} \mathrm{C}$ with a photo period of 14 hours light:10 hours dark. To ensure the validity of each of three independent experiments, positive, negative, and solvent controls were included in every experiment. 3,4-Dichloroaniline (4.0 mg/L) (Sigma-Aldrich), egg water, and DMSO (0.25\%) were used as positive, negative and solvent controls, respectively. The test was done in 5 days starting from the day of exposure (Day 0) and four follow up days (Days 1-4). At the end of the exposure period, acute toxicity (OECD 236, 
2013) and general morphology scores (GMS) (Beekhuijzen et al., 2015) were recorded every 24hr. The GMS was determined based on the scoring system with 12 developmental endpoints described by Beekhuijzen et al., (2015) while acute toxicity (lethality) was determined based on a positive outcome in any of four apical observations: (i) coagulation of fertilized egg, (ii) lack of somite formation, (iii) lack of detachment of the tail-bud from the yolk sac, and (iv) lack of heartbeat (OECD 236, 2013). In this GMS system, there are increasing numbers of indicators for morphology scoring at every observation time point, from $24 \mathrm{hpf}$ to $96 \mathrm{hpf}$. A lower GMS score indicates a higher degree of inhibition of the zebrafish embryo development in the ZET.

\subsection{Data analysis}

For each assay, at least three independent experiments were performed. Initial data analysis was done using Microsoft Excel 2016. Data from the ZET and EST assays were expressed as average scores while data from reporter gene assays were expressed as fold changes over the solvent control and for all assays, results are presented as mean values \pm SEM. Statistical significance was assessed using IBM SPSS Statistics 23. Results were compared by one-way analysis of variance (ANOVA) followed by Tukey HSD Post Hoc tests. Results with $p<0.05$ level of mean difference were considered significant. Graphing was made using GraphPad Prism software version 5.0 (California, USA). For the ZET and EST, nonlinear regression (curve fit) graphs of $\log ($ inhibitor) vs normalized response plots of mean and SEM were generated along with result sheets containing $\mathrm{IC}_{50}$ values (representing concentrations that decrease a given endpoint response by $50 \%$ ).

\section{Results}

\subsection{LC-MS based metabolomics profiling}

LC/MS data and MAGMa software based structural annotation revealed glucosinolates, alkaloids and amines as the common secondary metabolites in all the analysed extracts 
although other phytochemical groups such as phenolic compounds, terpenoids and iridoids were also detected in the leaf extract. Further definite identification confirmed the presence of glucosinolates (glucolepidin and glucobrassicin) and alkaloids or amines (stachydrine and trigonelline) as well as the possible absence of pyrrolizidine alkaloids. Moreover, although standard glucocapparin was not commercially available to confirm definite identification, the LC-MS/MS-MRM data supported its presence in all extracts.

\subsection{Derek Nexus toxicity predictions}

Derek prediction on the tentatively identified candidates indicated several alerts (endpoints) of toxicity hazards including genotoxicity and developmental toxicity with most of the annotated candidates that reflected toxicity hazards being detected in the leaf extract. Table S1 (supplementary materials) provides a detailed overview of all candidate constituents that fired structural alerts, Fig S1 (supplementary materials) shows examples of candidates as detected by LC/MS-MAGMa along with their toxicophores as detected by Derek predicition, while Table 1 shows some examples of target toxicophores in these toxicity predictions. Candidate molecules for which their definite identification in the extracts could be confirmed, such as glucosinolates and quaternary alkaloids both characterizing the Capparidaceae family (Delaveau et al., 1973) to which the study plant belongs, are part of the Derek predictions. For the glucosinolates, a carcinogenicity alert of open (no supporting or opposing evidence) likelihood level was fired. Isothiocyanates which are breakdown products of glucosinolates, raised a plausible alert for chromosome damage in vitro in mammalian systems, mutagenicity in vitro in bacteria, and skin sensitisation in mammals. The quaternary amines were linked to a plausible alert of causing irritation (of the eye and the skin) and an equivocal result for causing skin sensitisation in mammals. This study foccussed on results of the Derek toxicity predictions that raised concerns for genotoxicity and developmental toxicity, especially for 
some candidates in the leaf extract (Fig S1), while in the other extracts isothiocyanates formed from glucosinolates may raise a concern for genotoxicity.

Table 1. Summary of some examples of toxicophores (shaded grey) in candidate constituents of M. subcordata methanol extracts

\begin{tabular}{|c|c|c|}
\hline \multirow[t]{2}{*}{ Alerts (Toxicophores) } & \multicolumn{2}{|c|}{ Description of Derek Nexus toxicity prediction } \\
\hline & Prediction $\Rightarrow$ Alert fired (Endpoint) & Likelihood \\
\hline \multirow[b]{2}{*}{ Catechol } & Carcinogenicity in mammal & Plausible \\
\hline & Chromosome damage in vitro in mammal & Plausible \\
\hline \multirow[b]{2}{*}{ Conjugated alkene* } & Carcinogenicity in mammal & Plausible \\
\hline & Hepatotoxicity in mammal & Plausible \\
\hline \multirow{7}{*}{ Epoxide* } & Carcinogenicity in mammal & Plausible \\
\hline & Chromosome damage in vitro in mammal & Plausible \\
\hline & Chromosome damage in vivo in mammal & Plausible \\
\hline & Developmental toxicity in mammal & Plausible \\
\hline & Irritation (of the eye and skin) in mammal & Plausible \\
\hline & Mutagenicity in vitro in bacterium & Plausible \\
\hline & Mutagenicity in vitro in mammal & Plausible \\
\hline
\end{tabular}




\begin{tabular}{|l|l|l|}
\hline & Mutagenicity in vivo in mammal & Plausible \\
\hline \multirow{2}{*}{ Isothiocyanate } & Chromosome damage in vitro in mammal & Plausible \\
\cline { 2 - 3 } & Sutagenicity in vitro in bacterium & Plausible \\
\hline & Skin sensitisation in mammal & Plausible \\
\hline \multirow{2}{*}{ Quaternary ammonium } & Skin sensitisation in mammal & Plausible \\
\cline { 2 - 3 } & & Equivocal \\
\hline
\end{tabular}

* represent alerst from candidates detected only in the leaf extract

\subsection{The Ames test}

The Ames test indicated negative results (fold revertant colony count $<2$ ) (Fig.1a-f) for all the extracts at the tested concentrations while the positive controls, 4-nitroquinoline-N-oxide $(0.01 \mu \mathrm{g} /$ plate) and 2-aminoanthracene (2-AA, $1.0 \mu \mathrm{g} /$ plate) (Fig.1e\&f) show significant $(\mathrm{p}<0.001)$ positive mutagenicity. Because exposure to the higher concentrations (30 and 60 $\mathrm{mgDW} /$ plate) of the leaf extract with metabolic activation resulted in a fold change in colony counts of less than 1 compared to the solvent control, which may indicate cytotoxicity/ bactericidal effect, the plates were inspected under the microscope for any clearing or diminution of the background lawn (OECD, 1997) and the test for the leaf extract was repeated with lower concentrations $(7.5,15$, and $30 \mathrm{mgDW} /$ plate). Thus, results of the leaf extract also include a concentration of $7.5 \mathrm{mgDW} /$ plate and no significant decline in fold reverentant colony count was observed for the $30 \mathrm{gDW} /$ plate concentration in the repeated test (Fig.1b). Both the inspection and results of the repeated test showed no meaningful 
difference in fold change in colony counts apart from random variation indicating that the

390

391

392

393

394

(a)

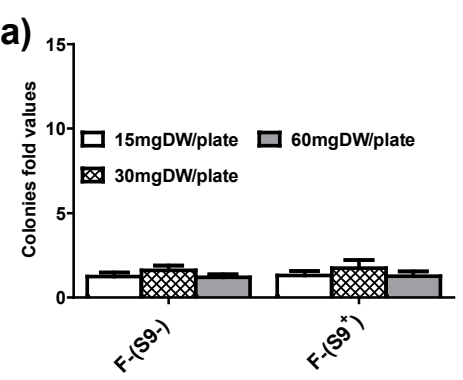

(d)

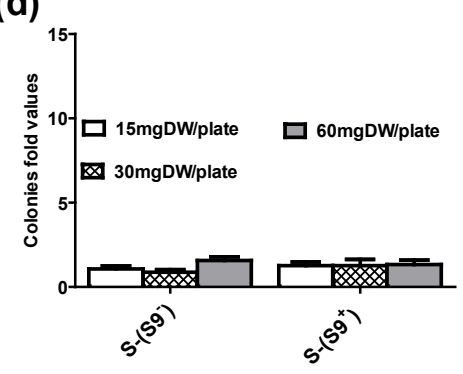

(b)

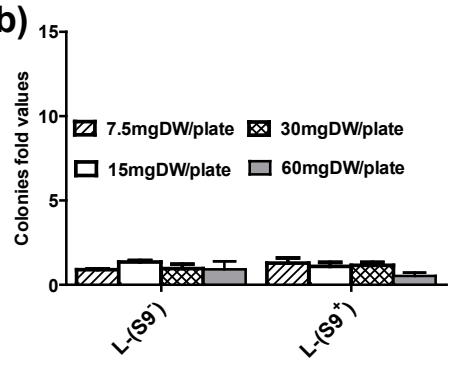

(e)

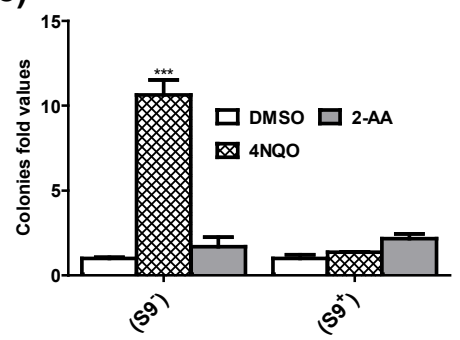

(c)

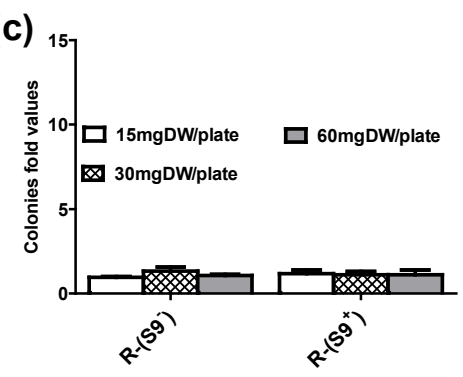

(f)

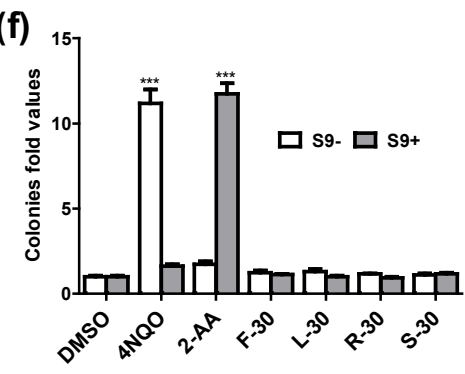

395

396

397

398

399

400

401

402

403

404

405

Figure 1. Ames test performed with (S9+) and without (S9-) metabolic activation, with Salmonella typhimurium TA98 for (a) fruit(F), (b) leaf(L), (c) $\operatorname{root}(\mathrm{R})$, and (d) $\operatorname{seed}(\mathrm{S})$ extracts of M. subcordata, using (e) DMSO as solvent control, 4-nitroquinoline-N-oxide (4NQO, $0.01 \mu \mathrm{g} /$ plate) and 2-aminoanthracene (2-AA, $1.0 \mu \mathrm{g} /$ plate) as positive controls, and (f) showing results of a similar test for the extracts (30 gDW/L) and controls done with $S$. typhimurium TA100. Results are described as fold values of average revertant colonies against the solvent control (DMSO) and are presented as mean \pm SEM from three experiments. Asterisks show a significant difference from the solvent control: $* * * p<0.001$.

\subsection{DR CALUX assay (AhR CALUX assay)}


406 AhR agonist activities of M. subcordata extracts were evaluated by the in vitro DR CALUX

407 assay as these endpoints were previously reported to play a useful role in an in vitro battery 408 of tests to detect developmental toxicity (Kamelia et al., 2017; Kamelia et al., 2018a,b).

409 Results show that upon $6 \mathrm{hr}$ exposure, the fruit, leaf, and seed extracts increased luciferase 410 activity in a concentration dependent manner while the root extract was almost lacking 411 activity in the concentration range tested (Fig.2a). A second set of experiments was 412 performed in which luciferase activity from cells exposed for different time periods (6 hr and $41324 \mathrm{hr}$ ) was quantified in order to check if the AhR induction was transient or persistent. The 414 results from the $6 \mathrm{hr}$ exposure reproduced the previous results while results from the $24 \mathrm{hr}$ 415 exposure showed that all extracts had little or no effect on luciferase activity (Fig.2b\&c) 416 although the extent of fold induction by TCDD from $24 \mathrm{hr}$ was increased nearly twofold as 417 compared to the $6 \mathrm{hr}$ exposure. 

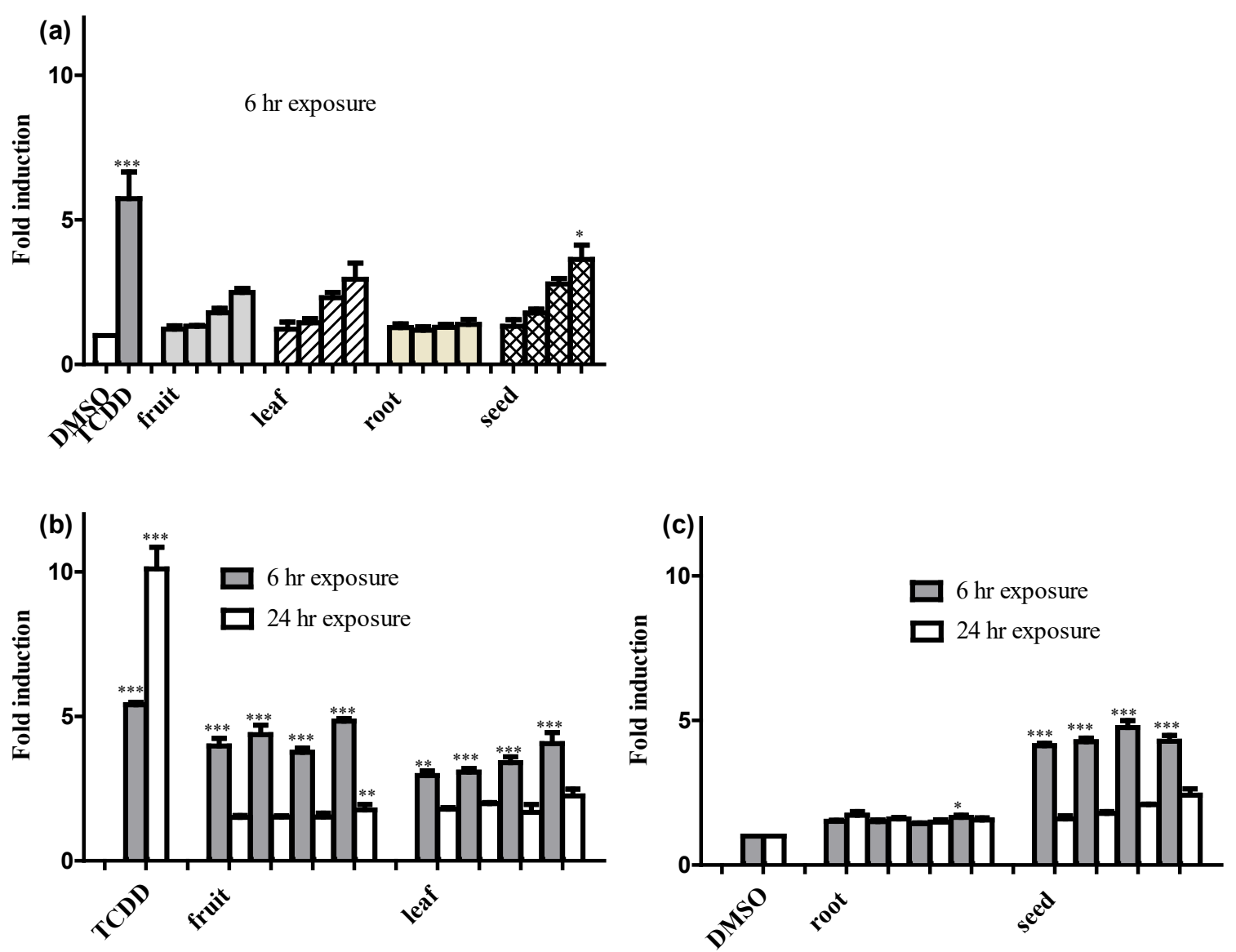

Figure 2. Induction of luciferase activity in rat hepatoma H4IIE-luc cells by TCDD at $30 \mathrm{pM}$

421 (positive control) and different concentrations of fruit, leaf, root, and seed extracts of $M$. subcordata after (a) $6 \mathrm{hr}$ exposure to the extracts at concentrations of $24,120,600$, and 3000 $\mathrm{mgDW} / \mathrm{L}$; (b and c) after $6 \mathrm{hr}$ and $24 \mathrm{hr}$ exposures to the extracts at concentrations of 1.5, 3, 6, and $12 \mathrm{gDW} / \mathrm{L}$. Results are described as fold induction of luciferase activity compared to $0.5 \%(\mathrm{v} / \mathrm{v}) \mathrm{DMSO}$ as a solvent control and data are presented as mean \pm SEM from at least three independent experiments. Asterisks show a significant difference from the solvent control: $* \mathrm{p}<0.05 ; * * \mathrm{p}<0.01 ; * * * \mathrm{p}<0.001$

\subsection{ERa CALUX and Cytotox CALUX assays}

430 ER $\alpha$ CALUX assay results (Fig.3) for M. subcordata methanol extracts show that the leaf extract at a concentration of $30 \mathrm{gDW} / \mathrm{L}$ increased $\mathrm{ER} \alpha$ mediated induction of luciferase 
activity with an average fold induction of $4.5 \pm 0.1$ compared to the solvent control. This effect was biologically relevant (fold induction $\geq 2$ ) (Yun and DasGupta, 2014) but statistically not significant ( $p>0.05)$ (Martı'nez-Abra1n, 2008). In the same experiment, 17- $\beta$-estradiol (E2) at $5 \mathrm{pM}$ displayed an average fold induction of $27.5 \pm 2.5(\mathrm{p}<0.0001)$. The fruit, the root, and the seed extracts did not induce luciferase activity in the U2OS ER $\alpha$ assay. Fig.3 also shows results of parallel screens in the cytotox CALUX assay which reflect luciferase activity similar to the solvent control implying the absence of any cytotoxicity or non-specific changes in luciferase activity as a result of exposure to the tested samples.

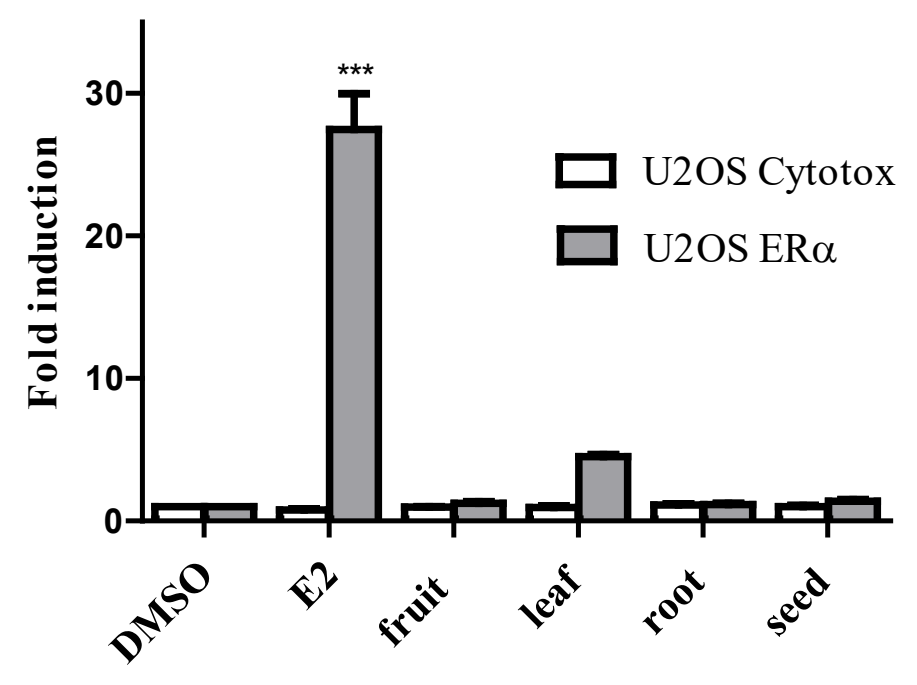

Figure 3. Induction of luciferase activity in U2OS ER $\alpha$ (shaded bars) and U2OS cytotox cells (white bars) cells after $24 \mathrm{hr}$ exposure to $5 \mathrm{pM}$ 17- $\beta$-estradiol (E2) (positive control) and M. subcordata fruit, leaf, root, and seed extracts at $30 \mathrm{gDW} / \mathrm{L}$. Results are expressed as fold induction of luciferase activity compared to $0.5 \%(\mathrm{v} / \mathrm{v})$ DMSO as solvent control. Data are presented as mean \pm SEM from three independent experiments. Asterisks show a significant difference from the solvent control: $* * * \mathrm{p}<0.001$. 


\subsection{ES-D3 cell viability and cell differentiation assays}

450

451

452

453

454

455

456

457

458

459

460

461

462

463

464

465

466

467

468

469

470

471

Results (Fig.4a-d) on the effects of M. subcordata extracts on the viability of ES-D3 cells showed that all extracts exhibited relatively similar effects ( $>89 \%$ cell viability) as the solvent control $0.25 \%(\mathrm{v} / \mathrm{v})$ DMSO, upon both one day and five days exposure, up to the highest tested concentration $(1500 \mathrm{mgDW} / \mathrm{L})$. As concentrations showing viability above $80 \%$ are generally accepted for further assays (Li et al., 2016; Queiroz et al., 2017), concentrations up to $1500 \mathrm{mgDW} / \mathrm{L}$ of all extracts were considered acceptable in the present study to further characterise effects on ES-D3 cell differentiation. Fig.4a-d also show the effects of the extracts on differentiation of ES-D3 cells into contracting cardiomyocytes, revealing that only the leaf extract significantly $(\mathrm{p}<0.001)$ inhibited ES-D3 cells differentiation at concentrations $\geq 750 \mathrm{mgDW} / \mathrm{L}$. 5-fluorouracil $(0.5 \mu \mathrm{M})$, used as a positive control, showed $85.42 \pm 5.51 \%$ inhibition of ES-D3 cells differentiation. Conversely, no inhibitory effect was shown by the root extract while the fruit and the seed extracts caused slight effects (26.7\% and $16.7 \%$ affected fractions, respectively) of inhibition at the highest concentration. The effect was statistically significant $(p<0.05)$ for the seed extract but not for the fruit extract although the later seem to show more effect may be because results of repeated experiments of the fruit extract had relatively higher variability compared to those from the seed extract. Only for the leaf extract an $\mathrm{IC}_{50}$ value $(209 \mathrm{mgDW} / \mathrm{L})$ could be derived from these data, representing the concentration that inhibits ES-D3 cell differentiation into beating cardiomyocytes by $50 \%$. As the extract was non-cytotoxic at the concentrations tested, cytotoxicity may not be expected to contribute to this inhibition of ES-D3 cell differentiation. 

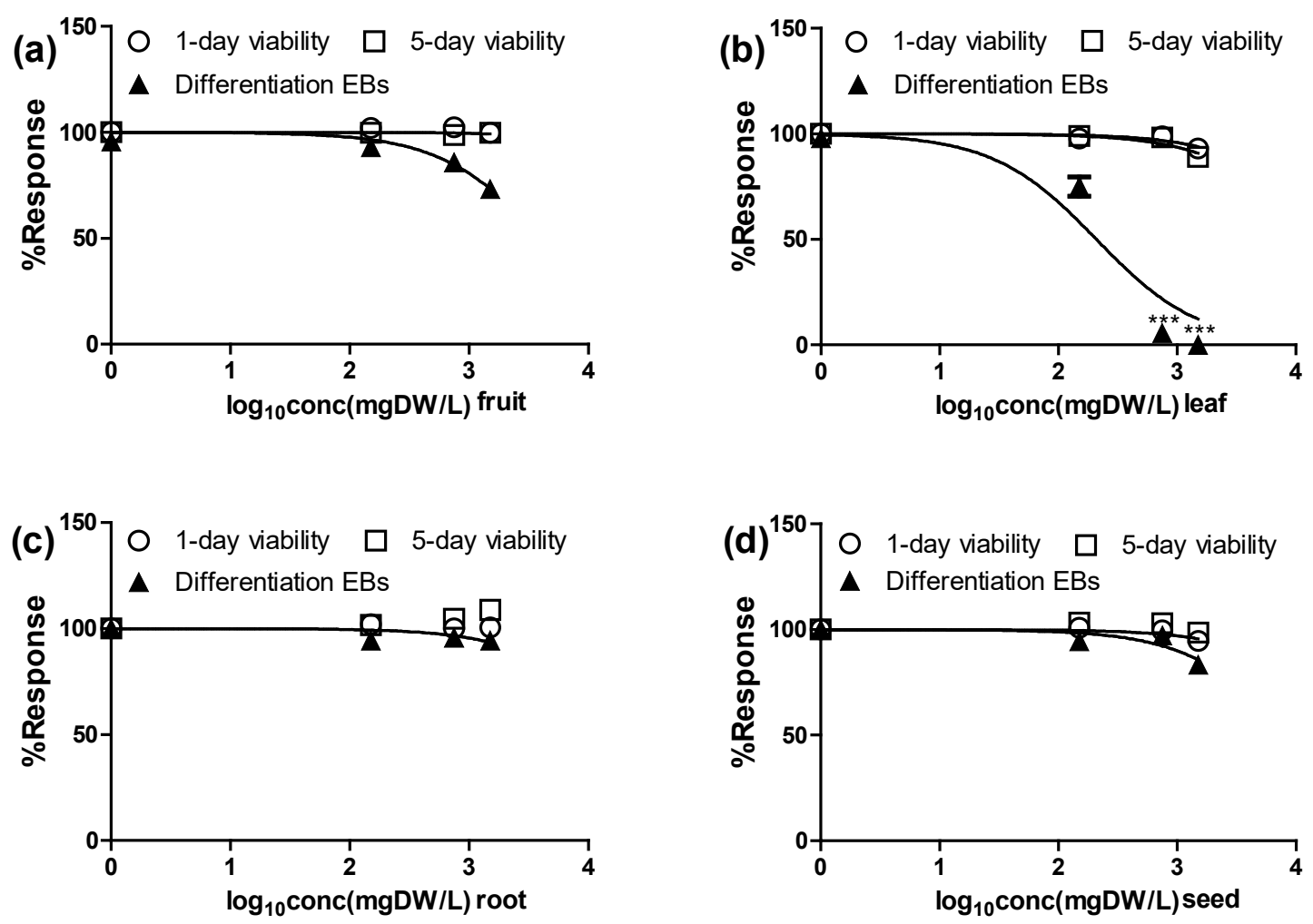

472

Figure 4. Effects of increasing concentrations (150-1500 mgDW/L) of M. subcordata fruit, leaf, root, and seed extracts on ES-D3 cells viability upon 1 day (black circles) and 5 days (black squares) exposures and on inhibition of ES-D3 cells differentiation into contracting cardiomyocytes upon a 10 days exposure (filled black triangles). Results represent mean \pm SEM from at least three independent experiments. Inhibition of ES-D3 cell differentitaion at concentrations where cytotoxicity is not yet observed indicated in vitro developmental toxicity. Asterisks show a significant difference from the solvent control: $* * * p<0.001$.

\subsection{Zebrafish embryotoxicity test (ZET)}

To further assess the in vitro acute toxicity and/or developmental toxicity potential of $M$. subcordata extracts, the effects of the extracts on lethality and/or on the general morphology of developing zebrafish embryos were determined by the ZET. Results (Fig.5a-d) show that for all concentrations of the tested extracts, the lethality and GMS records were almost 
overlapping and that in both records, the fruit extract at the highest concentration (1500 $\mathrm{mgDW} / \mathrm{L}, \mathrm{p}<0.05)$ and the leaf extract at $750 \mathrm{mgDW} / \mathrm{L}(\mathrm{p}<0.05)$ and $1500 \mathrm{mgDW} / \mathrm{L}(\mathrm{p}<0.01)$ induced statistically significant effects as compared to the internal control (IC) or negative control (egg water) and the solvent control $(0.25 \% \mathrm{DMSO})$ whereas the root and the seed extracts did not show statistically significant effects. 3,4-dichloroaniline $(4.0 \mu \mathrm{g} / \mathrm{ml})$, used as a positive control, induced a lethality of $98 \pm 1.67 \%$. Death of the zebrafish embryos occured either before $24 \mathrm{hpf}$ or immediately after hatching. Besides, occasional cases of malformation of the heart (abdominal and/or pericardial oedema, irregular shape due to edema or aplasia, abnormal heartbeat) (Beekhuijzen et al., 2015) in embryos exposed to all test extracts (0 to $5 \%$ incidence) but also to $0.25 \%(\mathrm{v} / \mathrm{v}) \mathrm{DMSO}(3.33 \%$ incidence) as well as few curved body/tail in dead embryos exposed to the fruit (1.67\% incidence) and the seed $(3.33 \%$ incidence) extracts were observed. Fig.6a-g show examples of normal and abnormal body morphology of some zebrafish embryos exposed to extracts of M. subcordata.

Because Selderslaghs et al., (2009) reported that DMSO, even at $0.5 \%(\mathrm{v} / \mathrm{v})$, caused adverse effects on the development of zebrafish embryos and proposed $0.25 \%(\mathrm{v} / \mathrm{v})$ DMSO (mean $\%$ larvae affected $<10$; not significantly different from controls) as the no observed effect concentration of DMSO, the $\leq 5 \%$ sub-lethal abnormalities (signs of malformation of the heart) (Fig.6c-d) observed in the present study were considered not significantly different from the control $(0.25 \%$ DMSO) and not biologically relevant. Besides, upon exposure to the fruit and seed extracts, some of the embryos that hatched during the time of observation were suffering from stiffness and staggered mobility. Few of the embryos that died immediately after hatching appeared to retain body shape similar to what they were inside the chorion while those that survived maintained normal body shape. Thus, the few cases of curved body/tail (Fig.6e-g) in dead embryos exposed to the fruit and seed extracts may be considered as symptoms of acute toxicity rather than a sign of abnormality since survivors 
511 did not show these effects. Also, despite that the fruit, root, and seed extracts had little or no 512 influence on hatchability, the leaf extract showed a significant $(p<0.01)$ effect at 513 concentrations $\geq 750 \mathrm{mgDW} / \mathrm{L}$ (Fig.5b). An $\mathrm{IC}_{50}$ value $(249 \mathrm{mgDW} / \mathrm{L})$ could be derived from 514 these data only for the leaf extract, representing the concentration that inhibit hatching by $51550 \%$ and implying that the $\mathrm{IC}_{50}$ values of the other extracts would be beyond the tested concentration range and hence reflecting little or no inhibitory effects on hatching.
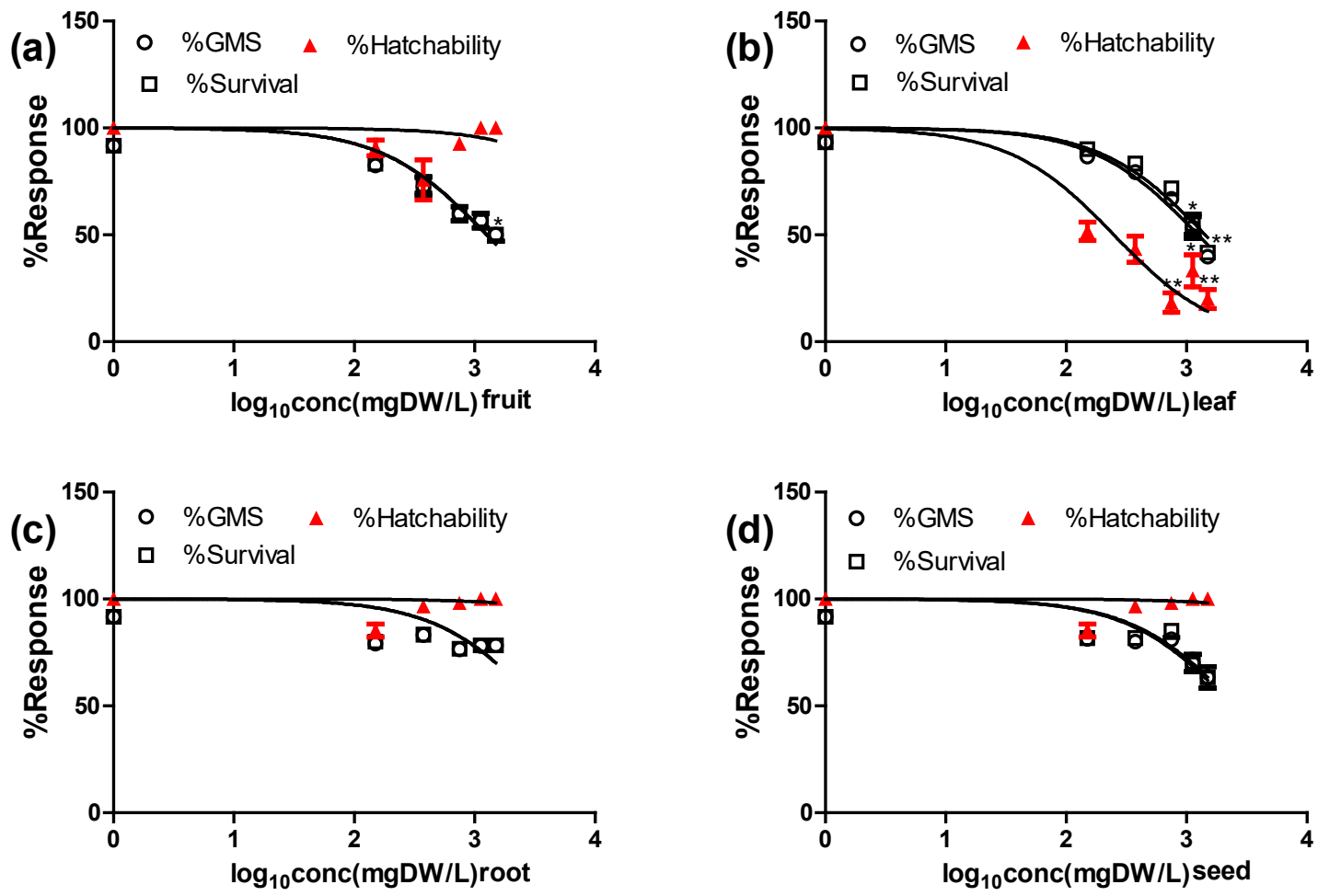

518

Figure 5. Effects of increasing concentrations (150, 375, 750, 1125, and $1500 \mathrm{mgDW} / \mathrm{L})$ of M. subcordata fruit, leaf, root, and seed extracts on zebrafish embryos as compared to solvent control on lethality (described as \%survival), general morphology scores (described as $\%$ GMS $)$, and \%hatchability. Results are described as mean \pm SEM of three independent experiments. Asterisks show a significant difference from the solvent control: ${ }^{*} \mathrm{p}<0.05 ; *{ }^{*} \mathrm{p}$ $<0.01$ 


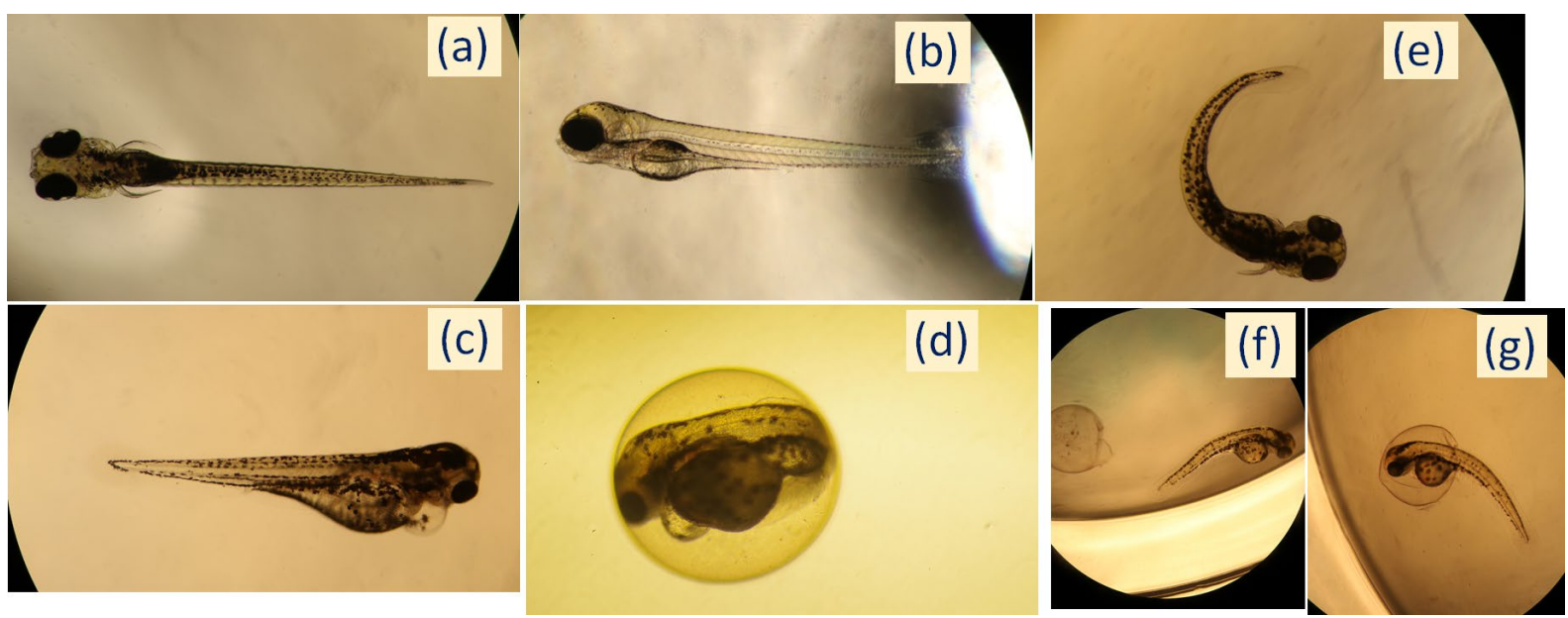

Figure 6. Examples of different morphologies of zebrafish embryos exposed to extracts of $M$. subcordata. (a-b) normal embryos at $96 \mathrm{hpf}$, (c-d) embryos with signs of malformation of the heart at $96 \mathrm{hpf}$, and (e-g) curved body/tail in dead embryos between 72-96 hpf.

\section{Discussion}

The present study applied different in vitro tests to assess the genotoxicity and developmental toxicity hazards of methanol extracts of the fruit, leaf, root, and seed parts of M. subcordata, a medicinal and (famine) food plant. These endpoints were selected based on the outcomes of a Derek Nexus toxicity prediction, performed on candidate structures obtained from metabolomics profiling of the extracts, and the fact that parts of the plants were reported to be used as abortifacient (Samuelsson et al. 1985, 1991).

538 Although plants are often thought to have anti-mutagenic effects against chemicals and environmental factors, they may also have mutagenic and cytotoxic effects (Erena and Özata, 2014). LC/MS-MAGMa metabolomics profiling plus Derek toxicity predictions showed that candidate constituents for especially the leaf extracts of M. subcordata point at genotoxicity 
hazards. In addition the glucosinolates, detected in all the extracts, may raise a concern because they usually degrade to isothiocyanates (ITCs) and ITCs are suspected of potential genotoxicity in some studies (Kassie et al., 2001) while they were also flagged as potentially genotoxic in the Derek predictions. Results of the present study, however, showed that $M$. subcordata extracts tested negative for mutagenicity in the Ames test, which overrules these concerns. The Ames test has been widely used to assess the mutagenicity of herbal products (Ouedraogo et al., 2012; Erena and Özata, 2014). Although a single test, i.e. the Ames test, cannot cover all genotoxic endpoints and especially does not exclude concerns in relation to chromosomal damage, in vitro bacterial reverse mutation test systems are likely to cover the majority of "critical" endpoints, i.e. DNA-reactivity, of herbal substances (EMEA, 2007). Thus, as the EU guidelines for herbal products define the Ames test as the primary endpoint to judge the genotoxicity (EMEA, 2007; Ouedraogo et al., 2012; Kelber et al., 2014), the results of the present study can be used to support the conclusion that these extracts may not raise a concern with respect to the genotoxicity of $M$. subcordata.

The current study also assessed a second endpoint of concern being developmental toxicity. Herbal remedies, being considered as 'harmless' and 'natural', are often used during pregnancy (Mohammed et al., 2016). Although there are generally insufficient data on the potential embryotoxicity of herbal remedies, some data indicate that their use during the early stages of pregnancy may not be safe for fetal development (Li et al., 2015; Mohammed et al., 2016). Therefore, the extracts were tested in a series of in vitro assays from a battery of tests developed to assess the in vitro developmental toxicity of complex substances (Kamelia et al., 2017; Kamelia et al., 2018a,b). These tests included the AhR CALUX assay, the ER $\alpha$ CALUX assay, the EST, and the ZET.

$\mathrm{AhR}$, being responsible for the induction of genes that contain a xenobiotic responsive element (XRE, sometimes called a dioxin responsive element) in their promoter regions 
567 (Hayes et al., 2009), was implicated in both drug metabolism as well as carcinogenic and toxicological responses against environmental contaminants such as TCDD, but was also shown to be of use in an alternative testing strategy for developmental toxicity (Kamelia et al., 2018). The AhR agonist activities of M. subcordata extracts, assessed by the rapid and sensitive in vitro CALUX assay (Aarts et al., 1995; Murk et al., 1996), showed time of exposure dependent variation. The AhR regulates both adaptive and toxic responses (Mitchell and Elferinka, 2009). Reports state that transient AhR activation by molecules like 6formylindolo[3,2-b]carbazole (FICZ), an endogenous ligand with greater binding affinity than TCDD, may be vital for the putative role of the AhR in cell homeostasis (Bock et al., 2013; Farmahin et al., 2016) while sustained AhR activation by molecules like TCDD culminates in toxic responses (Mitchell and Elferinka, 2009). Unlike TCDD mediated AhR activation, the AhR activation by $M$. subcordata extracts was of short duration resulting in a transient effect indicating that dioxin like toxicity by the extracts may be limited if not absent. However, AhR activation upregulates transcription of many genes, including those encoding members of the xenobiotic - metabolizing cytochrome P450 1 family of enzymes (CYP1s) (Bengtsson,, 2016) and induction or inhibition of CYP enzyme catalysed drug metabolism is among the most common pharmacokinetic interactions responsible for herb drug interactions (HDIs) that result in several significant HDI related adverse health effects (Koe et al., 2014; Wanwimolruk and Prachayasittikul, 2014; Onyeji et al., 2017). Therefore, possible adverse HDIs arising from modulation of the function of the AhR CYP system may be of relevance in cases of concurrent uses of certain drugs and the fruit, leaf, and seed extracts of $M$. subcordata.

Botanical related developmental toxicity may also arise from the endocrine-disrupting (ED) potential of certain plant metabolites, called phytoestrogens (Kristanc and Kreft, 2016). Many 
ED chemicals adversely impact estrogenic signalling by interacting with estrogen receptors

592 (Shanle and $\mathrm{Xu}, 2011$ ). Although various beneficial health effects have been ascribed to phytoestrogens, their (anti)oestrogenic properties have also raised concerns since they might act as endocrine disruptors, indicating a potential to cause adverse health effects including developmental toxicity (Rietjens et al., 2017). In this regard, only the leaf extract of $M$. subcordata induced some increase in luciferase activity (Fig.3) in the ER $\alpha$ CALUX assay, implying possible beneficial/adverse health effects while the activity of fruit, root, and seed extracts was similar to that of the solvent control implying a possible absence of agonistic estrogen activity.

In the EST assay, only the leaf extract of M. subcordata indicated possible developmental toxicity since it exhibited significant $(p<0.001)$ inhibition of differentiation of ES-D3 cells into contracting cardiomyocytes at non cytotoxic concentrations (Fig.4b). In the ZET test, the concentration response curves for lethality and GMS were quite similar (Fig.5a-d) suggesting that the GMS scores mostly came from acute toxicity (lethality) effects of the extracts rather than from abnormality endpoints. Malformation of the heart may indicate a teratogenicity 606 endpoint (Beekhuijzen et al., 2015) and this effect was observed in a very few $(\leq 5 \%)$ embryos upon exposure to all the tested extracts but also upon exposure to the DMSO solvent control, signifying the absence of a significant difference from the control (Selderslaghs et al., 2009). However, the leaf extract significantly $(\mathrm{p}<0.01)$ inhibited hatching $(\mathbf{F i g . 5 b})$ which was a major sub-lethal effect by the leaf extract but not induced by the fruit, root, and seed extracts or the solvent control. Hatching is part of the GMS but it is not an endpoint used to measure lethality. It ensures exposure of the embryo without a potential barrier function of the chorion, and as such may help data interpretation (OECD 236, 2013). Although David et al., (2016) reported that delay or failure to hatch may indicate teratogenic effects, this effect was not part of teratogenic endpoints as described by (Beekhuijzen et al. (2015) to assess 
developmental toxicity. Accordingly, the fruit, root, and seed extracts did not show any

617 obvious developmental toxicity (Beekhuijzen et al., 2015) apart from acute toxicity (OECD 236,2013 ) but the leaf extract may be suspected of posing such a hazard. Besides, the failure to hatch of the embryos exposed to the leaf extract might have compromised complete scoring of some endpoints such as deformed body shape which were scored on only the small fraction of hatched embryos.

To sum up, various ethno-medicinal claims on M. subcordata may point towards its potential uses as source of herbal medicine or functional or famine food. The different in vitro tests of the present study, summarized in Table 2, show that all extracts test negative in the Ames test with strain TA98 and TA100, both with and without metabolic activation and hence do not raise a concern for genotoxic hazard (EMEA, 2007); the root extract was apparently devoid of activity in all tests suggesting that further studies may consider the root as potential food item; the fruit and seed extracts seem to have minor toxicity effects except for the fact that they cause strong but transient AhR activation implying caution of, at least, HDI related adverse effects; the leaf extract showed effects in almost all tests except the Ames test indicating its potential multiple biological activities. Hence further studies considering its development and use as potential herbal medicine should also include an adequate safety and risk assessment focussing on at least its potential developmental toxicity. The overall results of the present study do not provide adverse-health effect based counter indications for the ethno-medicinal claim in the plant collection area, northern Ethiopia, that the root tuber part of the plant is a preferred antimalarial remedy for children and pregnant women when there is a fear that other herbal remedies may harm children or pregnant women. This is also in line with the general assumption that a long history of use of a botanical material in traditional medicine is an indicator of lack of obvious toxicity (Trease and Evans, 2002). 
Table 2. Summary of negative (-) or positive $(+)$ responses to a battery of toxicity tests applied in the present study to assess possible genotoxicity and developmental toxicity hazards of $M$. subcordata extracts.

\begin{tabular}{|c|c|c|c|c|c|}
\hline \multirow{2}{*}{$\begin{array}{l}\text { Assays/ } \\
\text { Tests }\end{array}$} & \multirow[t]{2}{*}{ Endpoints } & \multicolumn{4}{|c|}{ Response } \\
\hline & & Fruit & Leaf & Root & Seed \\
\hline Ames & Mutagenicity & - & - & - & - \\
\hline $\mathrm{ER} \alpha$ & Estrogenic agonist activity & - & + & - & - \\
\hline AhR & AhR agonist activity & + & + & - & + \\
\hline EST & Inhibition of embryonic stem cell differentiation & - & + & - & - \\
\hline \multirow[t]{2}{*}{ ZET } & Acute toxicity & + & + & - & - \\
\hline & Hatching inhibition & - & + & - & - \\
\hline
\end{tabular}

\section{Conclusion}

In conclusion, M. subcordata leaf extract showed a potential of multiple biological activities including activation of the aryl hydrocarbon receptor, activation of estrogen receptor alpha mediated gene expression, inhibition of embryonic ES-D3 stem cell differentiation into contracting cardiomyocytes, inhibition of hatching of zebrafish embryos, and acute toxicity to zebrafish embryos. These activities may imply potential pharmacological and/or toxicological consequences including developmental toxicity by the leaf extract. The fruit extract showed some cytotoxicity to zebrafish embryos and both the fruit and seed extracts showed induction of the aryl hydrocarbon receptor while the root extract was almost devoid of activity. Safe use of the fruit, root and seed extracts may be expected because hazards of genotoxicity and developmental toxicity as detected in the series of in vitro assays applied in the present study 
appeared limited if not absent. Yet, caution of herbal drug interactions arising from aryl

658

659

660

661

662

663

664

665

666

667

668

669

670

671

672

673

674

675

676

677

678

679

hydrocarbon receptor activation may be suggested in cases of concurrent uses of the fruit, leaf, and seed extracts with certain drugs.

\section{Acknowledgments}

This study was supported by NUFFIC - the Netherlands Fellowship Programmes, NFP PhD.15/0019 Contract number CF 09971. The authors are grateful to dr. PPJ (Patrick) Mulder at RIKILT, BU Contaminants \& Toxins, Wageningen for chemical analysis confirming the absence of pyrrolizidine alkaloids in the sample extracts. Further gratitude also goes to Alice Di Prima and Francesco Cucinottawho performed the Ames test with TA100.

\section{Conflicts of Interest}

The authors declare no conflict of interest.

\section{Authors contributions}

MGH did and handled all experimental activities, performed data interpretation, and wrote the manuscript. IMCMR supervised and helped the study starting from design of tests up to write up and editing of the manuscript. LK did the EST and helped in other in vitro tests, involved in reviewing and editing of the manuscript. SW and JV handled the LC-MS related tasks and edited the manuscript LH and BS assisted all experimental techniques, read and contributed to improve this manuscript.

\section{References}

Aarts, J.M., Denison, M.S., Cox, M.A., Schalk, M.A., Garrison, P.M., Tullis, K., de Haan, L.H.J., Brouwer, A., 1995. Species specific antagonism of Ah receptor action by 2, 2', 5, 5'-tetrachloro-and 2, 2', 3, 3'4, 4'-hexachlorobiphenyl. Eur. J. Pharmacol. 293, 463-474. 
680

681

682

683

684

685

686

687

688

689

690

691

692

693

694

695

696

697

698

699

700

701

702

703

704

Ames, B.N., Mccann, J., Yamasaki, E., 1975. Methods for Detecting Carcinogens and Mutagens with the Salmonella/Mammalian-Microsome Mutagenicity Test. Mut. Res. 31, 347-364.

Beekhuijzen, M., Koning, C., Flores-Guillénc, M.E., deVries-Buitenwega, S., ToborKaplona, M., Waart, B., Emmen, H., 2015. From cutting edge to guideline: A first step in harmonization of the zebrafish embryotoxicity test (ZET) by describing the mostoptimal test conditions and morphology scoring system. Reprod. Toxicol. 56, 64-76.

Bekki, K., Takigami, H., Suzaki, G., Tang, N., Hayakawa, K., 2009. Evaluation of Toxic Activities of Polyyclic Aromatic Hydrocarbon Derivatives Using In Vitro Bioassays. J. Health Sci. 55(4), 601-610.

Bengtsson, J., 2016. The impact of cytochrome P4501- inhibitors on aryl hydrocarbon receptor signaling. Department of Molecular Biosciences, the Wenner-Gren Institute Stockholm University, Sweden, pp. 1-60.

Besselink, H.T., Brouwer, A., Dang, Z., Bovee T., 2015. Validation of the (anti-) ER $\alpha$ CALUX bioassay U2OS cells Transcriptional ERalpha CALUX- assay for the detection of estrogenic and anti-estrogenic chemicals for inclusion in TG455. BioDetection Systems BV, pp. 1-102.

Bock, K.W., 2013. The human Ah receptor: hints from dioxin toxicities to deregulated target genes and physiological functions. Biol. Chem. 394(6), 729-39.

David, C.R.S., Angeles, A., Angoluan, R.C., Santos, J.P.E., David, E.S., Dulay, R.M.R., 2016. Moringa oleifera (Malunggay) Water Extracts Exhibit Embryo-toxic and Teratogenic Activity in Zebrafish (Danio rerio) Embryo Model. Der Pharm. Let. 8(7), 163-168.

Delaveau, P., Koudogbo, B., Pousset, J.L., 1973. Alcalojides Chezles Capparidaceae. Phytochem. 12, 2893-2895. 
EMEA., 2007. Guideline on the assessment of genotoxic constituents in herbal substances/ Preparations; EMEA/HMPC/107079/2007.

Erena, Y., Özata, A., 2014. Determination of mutagenic and cytotoxic effects of Limonium globuliferum aqueous extracts by Allium, Ames, and MTT tests. Rev. Bras. Farmacogn. $24,51-59$

Farmahin, R., Crump, D., O'Brien, J.M., Jones, S.P., Kennedy, S.W., 2016. Time-dependent transcriptomic and biochemical responses of 6-formylindolo[3,2-b]carbazole (FICZ) and 2,3,7,8-tetrachlorodibenzo-p-dioxin (TCDD) are explained by AHR activation time. Biochem. Pharmacol. 115, 134-43.

Fürst, R., Zündorf, I., 2015. Evidence-Based Phytotherapy in Europe: Where Do We Stand? Planta Med. 81(12-13), 962-7.

Gakuya, D.W., Mbaria, J.M., Mbithi, P.M.F., Munege, R.W., 2004. Evaluation of the Bioactivity of some Traditional Medicinal Plants using Brine Shrimp Lethality Test. Kenya vet. $26,8-11$

Göttsch, E., 1992. Purification of turbid surface water by plants in Ethiopia- Purification of turbid surface water by plants in Ethiopia: Moringa stenopetala. Walia 14,23-28.

Haedrich, J., Stumpf, C., Denison, M.S., 2018. Bioanalytical screening for Dioxins and PCBs in EU-regulated foods: new analytical criteria adopted by the European Union in Commission Regulation (EU) 2017/644. Part 2: sample analysis criteria and the nature of bioanalytical results. $114^{\text {th }}$ year of German Food Round Show, Behr's Verlag I Hamburg I ZKZ 9982.

Hayes, J.D., Dinkova-Kostova, A.T., McMahon, M. 2009. Cross-talk between transcription factors AhR and Nrf2: lessons for cancer chemoprevention from dioxin. Toxicol. Sci. 111(2), 199-201. 
Hoogenboom, L., Goeyens, L., Carbonnelle, S., van Loco, J., Beernaert, H., Baeyens, W., Traag, W., Bovee, T., Jacobs, G., Schoeters, G., 2006. The CALUX bioassay: Current status of its application to screening food and feed. Trends in Anal. Chem. 25 (4), 410420.

Kamelia, L., Brugman, S., de Haan, L., Ketelslegers, H.B., Rietjens, I.M.C.M., Boogaard, P.J., 2018a. Prenatal developmental toxicity testing of petroleum substances using the zebrafish embryotoxicity test. ALTEX. doi: 10.14573/altex.1808121.

Kamelia, L., Louisse, J., de Haan, L., Rietjens, I.M.C.M., Boogaard, P.J., 2017. Prenatal developmental toxicity testing of petroleum substances: Application of the mouse embryonic stem cell test (EST) to compare in vitro potencies with potencies observed in vivo. Toxicol. in Vitro 44, 303-312.

Kamelia, L., Louisse, J., de Haan, L., Maslowska-Gornicz, A., Ketelslegers, H.B., Brouwer, A., Rietjens, I.M.C.M., Boogaard, P.J., 2018b. The Role of Endocrine and Dioxin-Like Activity of Extracts of Petroleum Substances in Developmental Toxicity as Detected in a Panel of CALUX Reporter Gene Assays. Toxicol. Sci. 164(2), 576-591.

Kassie, F., Laky, B., Nobis, E., Kundi, M., Knasmüller, S., 2001. Genotoxic effects of methyl isothiocyanate. Mut. Res. 490, 1-9.

Kelber, O., Wegener, T., Steinhoff, B., Staiger, C., Wiesner, J., Knöss, W., Kraft, K., 2014. Assessment of genotoxicity of herbal medicinal products: Application of the "bracketing and matrixing" concept using the example of Valerianae radix (valerian root). Phytomed. 21,1124-1129.

Koe XF, Tengku Muhammad TS, Chong AS, Wahab HA, Tan ML., 2014. Cytochrome P450 induction properties of food and herbal-derived compounds using a novel multiplex RTqPCR in vitro assay, a drug-food interaction prediction tool. Food Sci. Nutr. 2(5), 500-20. 
753 Kristanc, L., Kreft, S., 2016. European medicinal and edible plants associated with subacute 754 and chronic toxicity part I: Plants with carcinogenic, teratogenic and endocrine-disrupting effects. Food Chem. Toxicol. 92,150-164.

756

Kroes, R., Walker, R., 2004. Safety issues of botanicals and botanical preparations in functional foods. Toxicol. 198(1-3), 213-20.

Kroese, D., Bosgra, S., Buist, H.E., Lewin, G., van der Linden, S.C., Man, H.Y., Piersma, A.H., Rorije, E., Schulpen, S.H.W., Schwarz, M., Uibel, F., van Vugt-Lussenburg, B.M.A., Wolterbeek A.P.M., van der Burg, B., 2015. Evaluation of an alternative in vitro test battery for detectingreproductive toxicants in a grouping context E. Reprod. Toxicol. $55,11-19$

Li, H., Flick, B., Rietjens, I.M.C.M., Louisse, J., Schneider, S., van Ravenzwaay, B., 2016. Extended evaluation on the ES-D3 cell differentiation assay combined with the BeWo transport model, to predict relative developmental toxicity of triazole compounds. Arch Toxicol. 90, 1225-1237.

Li, L.Y., Cao, F.F., Su, Z.J., Zhang, Q.H., Dai, X.Y., Xiao, X., Huang, Y.D., Zheng, Q., Xu, H., 2015. Assessment of the embryotoxicity of four Chinese herbal extracts using the embryonic stem cell test. Mol. Med. Rep. 12(2), 2348-54.

Little, J.G., Marsman, D.S., Baker, T.R., Mahony, C., 2017. In silico approach to safety of botanical dietary supplement ingredients utilizing constituent-level characterization. Food Chem. Toxicol. 107, 418-429.

Mahady, G.B., 2001. Global harmonization of herbal health claims. J. Nutr. 131(3s), 1120S$3 \mathrm{~S}$.

Martı'nez-Abrain A., 2008. Statistical significance and biological relevance: A call for a more cautious interpretation of results in ecology. acta oecologica 34, 9-11. 
Mitchell, K.A., Elferinka, C.J., 2009. Timing is everything: Consequences of transient and sustained AhR activity. Biochem. Pharmacol. 77(6), 947-956.

Mohammed, O.J., Latif, M.L., Pratten, M.K., 2016. Evaluation of embryotoxicity for major components of herbal extracts using the chick embryonic heart micromass and mouse D3 embryonic stem cell systems. Reprod. Toxicol. 59, 117-27.

Morgan, W.T.W., 1981. Ethnobotany of the Turkana: Use of Plants by a Pastoral People and their Livestock in Kenya'. Econ. Bot. 35(1), 96-130.

Murk, A.J., Legler, J., Denison, M.S., Giesy, J.P., Van de Guchte, C., Brouwer, A., 1996. Chemical-Activated Luciferase Gene Expression (CALUX): A Novel in Vitro Bioassay for Ah Receptor Active Compounds in Sediments and Pore Water. Fundam. Appl. Toxicol. 33:149-160.

OECD (471)., 1997. Guideline for Testing of Chemicals. Bacterial Reverse Mutation Test. OECD/OCDE 236., 2013. Fish Embryo Acute Toxicity (FET) Test. OECD Guidelines for the Testing of Chemicals.

Onyeji, C.O., Igbinoba, S.I., Olayiwola, G. 2017. Therapeutic Potentials and Cytochrome P450-Mediated Interactions Involving Herbal Products Indicated for Diabetes Mellitus. Drug Metab Lett. 11(2), 74-85.

Ouedraogo, M., Baudoux, T., Stévigny, C., Nortier, J., Colet, J.M., Efferth, T., Qu, F., Zhou, J., Chan, K., Shaw, D., Pelkonen, O., Duez, P., 2012. Review of current and "omics" methods for assessing the toxicity (genotoxicity, teratogenicity and nephrotoxicity) of herbal medicines and mushrooms. J. Ethnopharmacol. 140, 492- 512.

Paine, M.F., Roe, A.L., 2018. “Green Medicine”: The Past, Present, and Future of Botanicals. Clin. Pharmacol. Ther. 104(3), 410-415.

Piersma, A.H., 2013. Innovations in testing strategies in reproductive toxicology. Methods Mol. Biol. 947, 327-41. 
Piersma, A.H., Bosgra, S., van Duursen, M.B.M., Hermsena, S.A.B., Jonkere, L.R.A, Kroese, E.D., van der Linden, S.C., Man, H., Roelofs, M.J.E., Schulpen, S.H.W., Schwarz, M., Uibel, F., van Vugt-Lussenburg, B.M.A., Westerhout, J., Wolterbeek, A.P.M., van der Burg, B., 2013. Evaluation of an alternative in vitro test battery for detecting reproductive toxicants. Reprod. Toxicol. 38, 53-64.

Prinsloo, G., Papadi, G., Hiben, M.G., de Haan, L., Louisse, J., Beekmann, K., Vervoort, J., Rietjens, I.M.C.M., 2017. In vitro bioassays to evaluate beneficial and adverse health effects of botanicals: promises and pitfalls. Drug Discov. Today, 22(8), 1187-1200.

Queiroz, T.B., Santos, G.F., Ventura, S.C., Hiruma-Lima, C.A., Gaivão, I.O.M., Maistro, E.L., 2017. Cytotoxic and genotoxic potential of geraniol in peripheral blood mononuclear cells and human hepatoma cell line (HepG2). Genet. Mol. Res. 16 (3), gmr16039777.

Ridder, L., van der Hooft, J.J.J., Verhoeven, S., de Vos, R.C.H., van Schaik, R., Vervoort, J., 2012. Substructure-based annotation of high-resolution multistage MSn spectral trees. Rapid Commun. Mass Spectrom. 26, 2461-2471.

Rietjens, I.M.C.M., Louisse, J., Beekmann, K., 2017. The potential health effects of dietary Phytoestrogens. British J. Pharmacol. 174, 1263-1280.

Rietjens, I.M.C.M., Slob, W., Galli, C., Silano, V., 2008. Risk assessment of botanicals and botanical preparations intended for use in food and food supplements: emerging issues. Toxicol. Lett. 180(2), 131-6.

Roe, A.L., McMillan, D.A., Mahony, C., 2018. A Tiered Approach for the Evaluation of the Safety of Botanicals Used as Dietary Supplements: An Industry Strategy. Clin. Pharmacol. Ther. 104(3), 446-457.

Salehi, B., Valussi, M., Jugran, A.K., Martorell, M., Ramírez-Alarcón, K., StojanovićRadić, Z.Z. Antolak, H., Kręgiel, D., Mileski, K.S., Sharifi-Rad, M.,. Setzer, W.N, Cádiz- 
Gurrea, M.L., Segura-Carretero, A., Şenerm, B., Sharifi-Rad, J., 2018. Nepeta species: From farm to food applications and phytotherapy Trends in Food Sci. \& Technol. 80, 104-122.

Samuelsson, G., Farah, M.H., Claeson, P., Hagos, M., Thulin, M., Hedbers, O., Warfa, A.M., Hassan, A.O., Elmi, A.H., Abdurahman, A.D., et al. 1991. Inventory of plants used in traditional medicine in Somalia. I. Plants of the families Acanthaceae-Chenopodiaceae. J. Ethnopharmacol. 35, 25-63.

Samuelsson, G., Kyerematen, G., Farah, M.H., 1985. Preliminary chemical characterization of pharmacologically active compounds in aqueous plant extracts. J. Ethnopharmacol. $14,193-201$.

Schilter, B., Andersson, C., Anton, R., Constable, A., Kleiner, J., O'Brien, J., Renwick, A.G.,

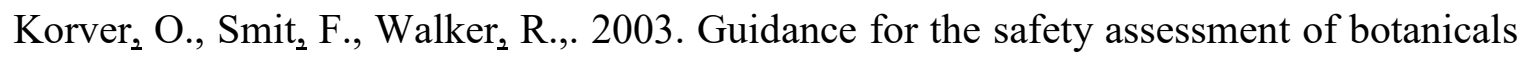
and botanical preparations for use in food and food supplements. Food Chem. Toxicol. 41(12), 1625-49.

Selderslaghs, I.W.T., Van Rompay, A.R., Coen, W.D., Witters, H.E., 2009. Development of a screening assay to identify teratogenic and embryotoxic chemicals using the zebrafish embryo. Reprod. Toxicol. 28, 308-320.

Shanle, E.K., Xu, W., 2011. Endocrine disrupting chemicals targeting estrogen receptor signaling: Identification and mechanisms of action. Chem. Res. Toxicol. 24(1), 6-19.

Sharifi-Rad, M., Ozcelik, B., Altın, G., Daşkaya-Dikmen, C., Martorell, M., RamírezAlarcón, K., Alarcón-Zapata, P., Morais-Braga, M.F.B., Carneiro J.N.P., Leal A.L.A.B., Coutinho, H.D.M., Gyawali, R., Tahergorabi R., Ibrahim S.A., Sahrifi-Rad R., Sharopov F., Salehi B., Contreras, M.M., Segura-Carretero A., Sen, S., Acharya, K., Sharifi-Rad, J., 2018. Salvia spp. plants-from farm to food applications and phytopharmacotherapy Trends in Food Sci. \& Technol. 80, 242-263. 
852 Strauch, A.M, Eby, S., 2012. The influence of fire frequency on the abundance of Maerua 853 subcordata in the Serengeti National Park, Tanzania. J. Plant Ecol. 5(4), 400-406.

854 Trease, G.E., Evans, W.C., 2002. Pharmacognosy. $15^{\text {th }}$ ed. London, UK: Bailliere Tindall.

855 van der Linden, S.C., von Bergh, A.R.M., van Vught-Lussenburga, B.M.A., Jonkera, L.R.A., 856 Teunis M, Krul, C.A.M., van der Burg, B., 2014. Development of a panel of high857 throughput reporter-gene assays to detect genotoxicity and oxidative stress. Mut. Res. $760,23-32$.

Wanwimolruk, S., Prachayasittikul, V., 2014. Cytochrome P450 Enzyme Mediated Herbal 860 Drug Interactions (Part 1) Excli. J. 13, 347-391.

Wigrup, I., 2005. The Role of Indigenous Knowledge in Forest Management. A Case Study from Masol and Sook Division, West Pokot, Kenya. Department of Silviculture Swedish University of Agricultural Sciences Umeå.

864 Worth, A., Lapenna, S., Piparo, E.L., Mostrag-Szlichtyng, A., Serafimova, R., 2010. The Applicability of Software Tools for Genotoxicity and Carcinogenicity Prediction: Case Studies relevant to the Assessment of Pesticides; European Union.

Yun, C., DasGupta, R., 2014. Luciferase reporter assay in Drosophila and mammalian tissue culture cells Curr. Protoc. Chem. Biol, 6(1), 7-23. 